\title{
Prochlorophytes as secondary prey for heterotrophic nanoflagellates in the deep chlorophyll maximum layer of the (sub)tropical North Atlantic
}

\author{
Bouwe R. Kuipers*, Harry J. Witte \\ Department of Biological Oceanography, Netherlands Institute of Sea Research, PO Box 59, 1790 AB Den Burg, \\ The Netherlands
}

\begin{abstract}
Growth rates in prochlorophytes and their loss rates to grazing were investigated by the dilution technique in the lower euphotic zone of the (sub)tropical North Atlantic. Directly above the 'deep chlorophyll maximum' (DCM), prochlorophyte growth rates were approximately $0.3 \mathrm{~d}^{-1}$ and grazing rates $0.4 \mathrm{~d}^{-1}$; both rates were considerably lower in and directly below the DCM. Grazing was only weakly affected by filtration through $3 \mu \mathrm{m}$ pore-size filters, indicating heterotrophic nanoflagellates as the main grazers. Discrimination between day and night revealed that the prochlorophytes above the DCM, with doubling times of $3 \mathrm{~d}$ or more, divided during the day whereas at greater depth division occurred during the night. In contrast, grazing was always restricted to the daylight period and grazing rate was independent of prochlorophyte abundance, growth rate or time of division. Prochlorophyte grazing rates were, however, correlated with the loss rates in the much more abundant heterotrophic bacteria in the same layers. We conclude therefore that prochlorophytes are consumed as a secondary prey by heterotrophic nanoflagellates grazing on heterotrophic bacteria.
\end{abstract}

KEY WORDS: Prochlorophytes · Heterotrophic bacteria $\cdot$ Grazing $\cdot$ Heterotrophic nanoflagellates · Deep chlorophyll maximum · North Atlantic Ocean

\section{INTRODUCTION}

Oligotrophic tropical and subtropical oceans are typically inhabited by a pico- and nanoplankton community dominated by heterotrophic bacteria, prochlorophytes, cyanobacteria and, to a lesser extent, autotrophic and heterotrophic nanoflagellates (Claustre \& Marty 1995, Landry et al. 1996, Partensky et al. 1996). A fluorescence maximum, usually referred to as the 'deep chlorophyll maximum' (DCM) marks the transition zone between the nutrient-depleted euphotic layer and the nutrient-rich water below the thermocline (Gieskes \& Kraay 1986, Olson et al. 1990, Li et al. 1992, Neveux 1992, Campbell \& Vaulot 1993, Landry et al. 1996). In these warm ocean areas, Prochlorococcus spp. is always the most abundant pho-

*E-mail: bouwe@nioz.nl tosynthetic population (Partensky et al. 1999 and references therein), and the DCM in the (sub)tropical North Atlantic is generally accepted to be caused by the enhanced chlorophyll content of the prochlorophyte cells near the bottom of the euphotic zone (McManus \& Dawson 1994, Claustre \& Marty 1995). At the DCM depth, irradiance levels decrease to values close to $0.1 \%$ of the surface irradiation. Specific adaptation in the composition of the pigments and the pigment content per cell in the prochlorophytes in these layers (Veldhuis \& Kraay 1990, Goericke \& Repeta 1992, 1993, Neveux 1992, Shimada et al. 1993, McManus \& Dawson 1994, Jochem 1995) allows them to inhabit this particular environment, where irradiance is close to or below the compensation level for eukaryotic algae (Kirk 1983) but where inorganic nutrients from the nutrient-rich waters below the thermocline penetrate upwards by mixing and diffusion. 
Thus, in the open (sub)tropical North Atlantic, the nutrient and irradiation conditions in which prochlorophytes occur range from nutrient depletion and extremely high irradiance levels near the surface to severe light limitation and potentially high nutrient availability at the nitracline (Olson et al. 1990, Vaulot \& Partensky 1992, Partensky et al. 1999). Diel patterns in growth and grazing under such contrasting conditions may differ greatly. Since these (sub)tropical water masses are permanently stratified, there is probably a succession with depth of different (sub)species of prochlorophytes or at least different strains (Campbell \& Vaulot 1993, Bisset et al. 1999, Partensky et al. 1999). In the present paper we specifically focused on the growth and grazing rates and their diel patterns in prochlorophytes in different layers of the (sub)tropical North Atlantic. We presumed that these would change along the depth gradient, especially in the lower part of the euphotic zone where the growth limitation changes with depth from nutrients to light. We tested this hypothesis by determining the dynamics in prochlorophyte growth and grazing loss as estimated by serial dilution experiments (Landry \& Hassett 1982) with water samples from above and below and from within the DCM at 5 stations across the (sub)tropical North Atlantic.

\section{MATERIALS AND METHODS}

In the summer of 1996, 5 stations between $10^{\circ}$ and $35^{\circ} \mathrm{N}$ in the tropical and subtropical Atlantic (Fig. 1) were visited with HRMS 'Tydeman' for an extensive study of the physics in the upper $250 \mathrm{~m}$ of the water column and the planktonic food web in the DCM. The $5 \mathrm{~d}$ program at each station included frequent sampling with a CTD-rosette system with 24 (10 l) NOEX (Technicap-CAP D'AIL, France) bottles from $250 \mathrm{~m}$ up-

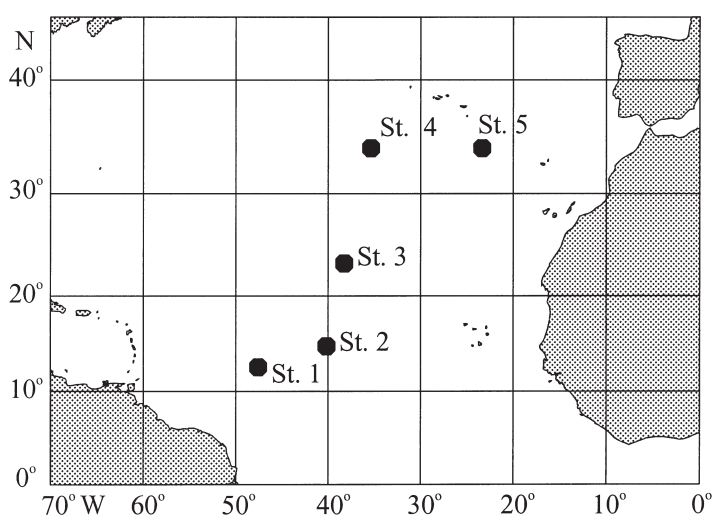

Fig. 1. Sampling stations (1 to 5) of the 1996 cruise with HRMS 'Tydeman' in North Atlantic wards at different times of the day. Fig. 2 gives the vertical profiles at 12:00 h local time of light intensity and fluorescence as provided by the CTD system and the measured $\mathrm{NO}_{3}$-concentrations, while data on temperature, salinity, other nutrients and chlorophyll $a$ are presented in Table 1 (all methods according to the Joint Global Ocean Flux Study (JGOFS) standards: see Kuipers et al. 2000). Incubations to estimate grazing were prepared according to the dilution method of Landry \& Hassett (1982) at each of the 5 stations. Per station, three $24 \mathrm{~h}$ incubations were prepared on consecutive days with water samples from each of 3 investigated strata in the DCM. The samples were taken at the depth of maximum fluorescence at about $100 \mathrm{~m}$ (henceforth referred to as 'central $\mathrm{DCM}^{\prime}$ ), and at half the peak fluorescence above ('upper $\mathrm{DCM}^{\prime}$ ) and below ('lower DCM') the maximum. Because the depth and the shape of the fluorescence peak oscillated with the internal waves, the sampling depths were determined shortly before the actual sampling using the fluorescence profile measured by the CTD-rosette system during the downcast. The grazing incubations lasted $24 \mathrm{~h}$ and started with slowly filling a darkened $20 \mathrm{l}$ carboy with the content of 2 NOEX bottles closed at the same depth around 08:00 h local time. In a temperature-controlled container, $10 \mathrm{l}$ of the sample was filtered through a Gelman Micro Culture Capsule $(0.2 \mu \mathrm{m})$ to produce particle-free water for the dilution series, which was checked (by flow cytometry) for particles before use. Of 18 (300 ml) polycarbonate bottles prepared for each dilution series, 4 were filled to 100 , 3 to 70,4 to 40,3 to 20 and 4 to $10 \%$ with $200 \mu \mathrm{m}$ screened natural water (through a Nitex mesh to remove mesozooplankton), and filled up with the $0.2 \mu \mathrm{m}$ filtered water from the same depth. All bottles were mounted on a slowly rotating $(0.5 \mathrm{rpm})$ plankton wheel at in situ temperature and an appropriate light level (partly covered Sylvania daylight TL-tube, estimated level in the bottles approximately $10 \mu \mathrm{E} \mathrm{m}^{-2} \mathrm{~s}^{-1}, 12: 12 \mathrm{~h}$ $\mathrm{L}: \mathrm{D}$ cycle) for $24 \mathrm{~h}$. At the start of the incubation, $4 \mathrm{ml}$ samples were taken from all bottles and replaced by $4 \mathrm{ml}$ particle-free water to prevent air bubbles. The samples were immediately placed on ice and the prochlorophytes and other autotrophic cells enumerated in a flow cytometer (Coulter XL-MCL). The time of this first sampling from the bottles was taken as the $t_{0}$ of the incubation. In the flow cytometer plots of autofluorescence versus side-scatter of all particles, the prochlorophytes from our 3 relatively deep investigation layers could be clearly separated from the noise and the larger autotrophs due to through their relatively high autofluorescence. A check on the consistency of the flow cytometer enumeration over a wide range of concentrations of prochlorophytes was done by comparing the flow cytometer counts in the differ- 

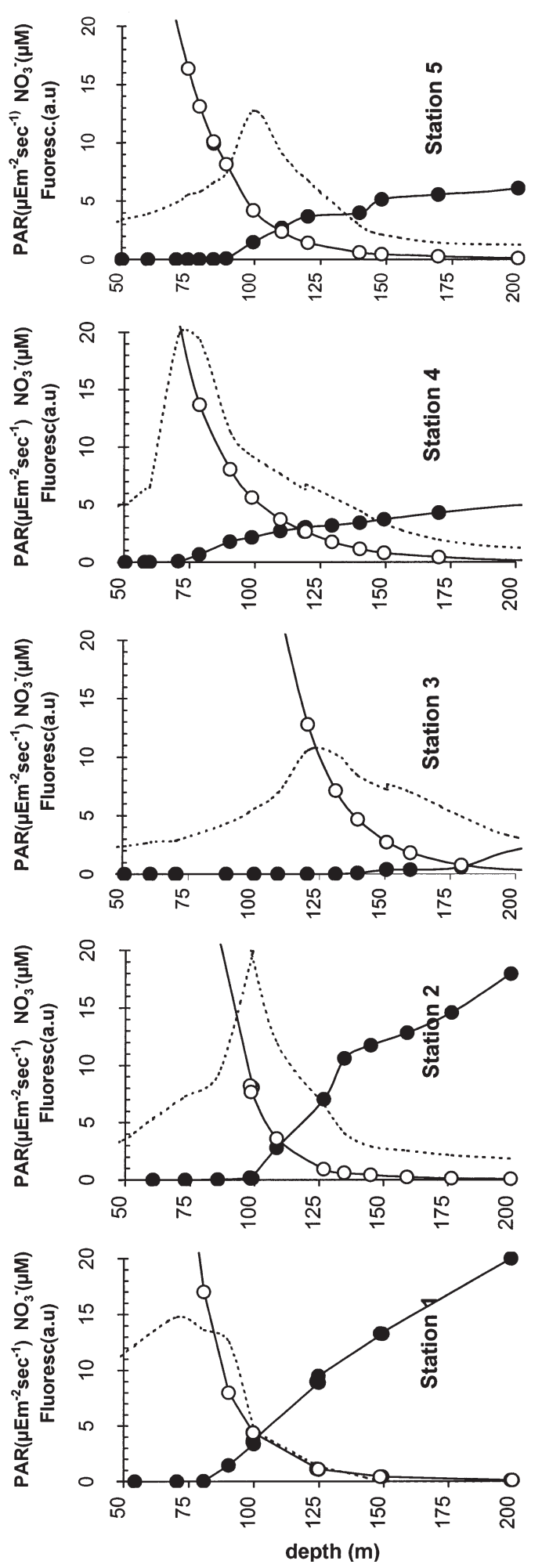

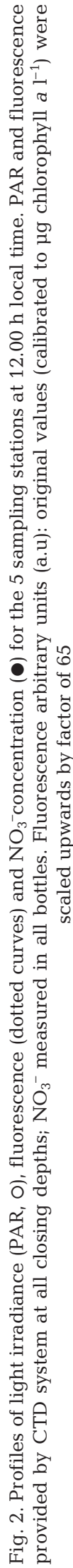

ent dilutions at $t_{0}$ with the predicted numbers based on the dilution.

In order to obtain information on the size of the micro-heterotrophs grazing on the prochlorophytes (they could be predominantly heterotrophic nanoflagellates [HNANs] but possibly also small ciliated Protozoa), separate bottles were prepared in which the natural water was filtered by gravity through 10, 5 and $3 \mu \mathrm{m}$ pore-size polycarbonate filters. For each of these pore sizes, $4(300 \mathrm{ml})$ incubation bottles $(2 \times 100$ and 2 $\times 40 \%$ prescreened natural water) were prepared and held under the same conditions as the incubations to assess prochlorophyte grazing by the whole microzooplankton community.

Additional to the experiments performed on the plankton wheel and under artificial light conditions, in situ grazing experiments were performed. Polycarbonate bottles $(80 \mathrm{ml}$ vol), attached to the buoy used for in situ incubation, were fixed to the line at 2 depths (upper and central DCM). At Stns 2 and 3 in situ incubations were done only in the central DCM; at Stn 4 only in the upper DCM. For these incubations, natural water was taken from NOEX bottles from the respective depth from the 04:00 h CTD-rosette cast and kept in the dark in a temperature-controlled container until the dilution series were prepared shortly before 06:00 h. Two series of 3 different dilutions (100, 50 and 10\%) were prepared in duplicate with the natural water gravity-filtered through 3 and $5 \mu \mathrm{m}$ polycarbonate filters to size-fractionate the grazer community. The in situ incubations were lowered at 06:00 h local time (shortly before sunrise), and the buoy was recovered at 18:00 h (after sunset). After recovery of the bottles, samples were taken for flow cytometric enumeration. Finally, the bottles were filled with $4 \mathrm{ml} 0.2 \mu \mathrm{m}$-filtered seawater from the respective depths and placed on the plankton wheel in darkness to simulate the night conditions for another $12 \mathrm{~h}$. Following this incubation, samples were withdrawn from the bottles at 6:00 $\mathrm{h}$ the next morning $(t=24 \mathrm{~h})$. The dilution series provided hourly growth rates $\left(\mu \mathrm{h}^{-1}\right)$ and grazing rates $\left(g \mathrm{~h}^{-1}\right)$ according to the equation $N_{t}=N_{0} \mathrm{e}^{(\mu-g) t}$; for comparison with literature data daily rates $\left(\mu \mathrm{d}^{-1}\right.$ and $\left.g \mathrm{~d}^{-1}\right)$ were used (see Kuipers \& Witte 1999).

\section{RESULTS}

\section{$24 \mathrm{~h}$ deck incubations}

The results of the 14 serial dilution experiments with prescreening over $200 \mu \mathrm{m}$ mesh and incubating for $24 \mathrm{~h}$ on the plankton wheel are given in Table 2, together with the initial prochlorophyte abundance. Their calculated gross growth rate $(\mu)$ and loss rate due to grazing $(g)$ for the 3 DCM layers are shown in Fig. 3. 
Table 1. Local time, temperature and salinity at 12:00 h at the 5 stations (CTD system, upcast data) and measured nutrient- and chlorophyll a concentrations (irradiance and fluorescence at 12:00 h given in Fig. 2; all measurements according to JGOFS standards; for details of methods see Kuipers et al. 2000)

\begin{tabular}{|c|c|c|c|c|c|c|}
\hline Depth (m) & Temperature $\left({ }^{\circ} \mathrm{C}\right)$ & Salinity (\%o) & $\mathrm{PO}_{4}(\mu \mathrm{M})$ & $\mathrm{NO}_{3}(\mu \mathrm{M})$ & $\mathrm{NH}_{4}(\mu \mathrm{M})$ & Chl a $\left(\mu \mathrm{gl}^{-1}\right)$ \\
\hline \multicolumn{7}{|l|}{ Stn 1} \\
\hline 20 & 27.7 & 36.0 & 0.03 & 0.00 & 0.16 & 0.14 \\
\hline 50 & 27.6 & 36.1 & 0.02 & 0.00 & 0.16 & 0.24 \\
\hline 100 & 22.9 & 36.5 & 0.25 & 3.43 & 0.14 & 0.10 \\
\hline 200 & 13.9 & 35.7 & 1.39 & 21.70 & 0.21 & 0.01 \\
\hline \multicolumn{7}{|l|}{ Stn 2} \\
\hline 20 & 26.5 & 36.6 & 0.04 & 0.00 & 0.14 & - \\
\hline 50 & 26.4 & 36.6 & 0.03 & 0.00 & 0.14 & 0.15 \\
\hline 100 & 22.3 & 36.9 & 0.10 & 0.10 & 0.16 & 0.26 \\
\hline 200 & 15.6 & 36.1 & 1.10 & 18.00 & 0.13 & 0.00 \\
\hline \multicolumn{7}{|l|}{ Stn 3} \\
\hline 20 & 25.4 & 37.6 & 0.02 & 0.00 & 0.25 & - \\
\hline 50 & 25.2 & 37.6 & 0.02 & 0.00 & 0.24 & 0.07 \\
\hline 100 & 21.9 & 37.3 & 0.02 & 0.00 & 0.25 & 0.18 \\
\hline 200 & 18.6 & 36.7 & 0.07 & 2.06 & 0.21 & 0.06 \\
\hline \multicolumn{7}{|l|}{ Stn 4} \\
\hline 20 & 26.2 & 37.0 & 0.04 & 0.00 & 0.21 & - \\
\hline 50 & 19.1 & 36.6 & 0.00 & 0.00 & 0.12 & 0.10 \\
\hline 100 & 18.2 & 36.6 & 0.10 & 2.14 & 0.20 & 0.21 \\
\hline 200 & 17.2 & 36.4 & 0.26 & 4.93 & 0.16 & 0.02 \\
\hline \multicolumn{7}{|l|}{ Stn 5} \\
\hline 20 & 24.7 & 36.8 & 0.03 & 0.00 & 0.18 & - \\
\hline 50 & 20.5 & 36.6 & 0.02 & 0.00 & 0.18 & 0.11 \\
\hline 100 & 17.5 & 36.4 & 0.13 & 1.48 & 0.12 & 0.21 \\
\hline 200 & 15.8 & 36.2 & 0.40 & 6.08 & 0.14 & 0.02 \\
\hline \multicolumn{7}{|l|}{ Averages: } \\
\hline \multicolumn{3}{|c|}{20 to $50 \mathrm{~m}$ (mixed zone) } & 0.025 & 0.000 & 0.178 & 0.135 \\
\hline \multicolumn{3}{|c|}{$100 \mathrm{~m}$ (fluorescence max.) } & 0.120 & 1.430 & 0.174 & 0.192 \\
\hline \multicolumn{3}{|c|}{200 m (aphotic zone) } & 0.644 & 10.554 & 0.170 & 0.022 \\
\hline
\end{tabular}

In the upper DCM, the gross growth rate $(\mu)$ of prochlorophytes varied from 0.18 to $0.25 \mathrm{~d}^{-1}$ at 4 of the 5 stations, whereas the grazing rate $(g)$ ranged from 0.15 to $0.41 \mathrm{~d}^{-1}$ at all 5 stations. At Stn 3, the prochlorophytes in the upper DCM incubation series were grazed at a rate of $0.32 \mathrm{~d}^{-1}$ but did not grow $(\mu=$ $0.03 \mathrm{~d}^{-1}$ ).

In the central DCM, the $24 \mathrm{~h}$ incubations resulted in low prochlorophyte gross growth rates at Stns 1, 4 and 5 ( $\mu$ of $0.10,0.16$ and $0.06 \mathrm{~d}^{-1}$, respectively) and negative growth rates at Stns 2 and 3 ( $\mu$ of -0.11 and $-0.01 \mathrm{~d}^{-1}$, respectively). There was no detectable grazing in the central DCM at Stns 1, 2 and 3 (i.e. $\mathrm{g}<$ $0.015 \mathrm{~d}^{-1}$ ), and only weak grazing at Stns 4 and 5 .

In the lower DCM, representing the aphotic zone below the fluorescence peak, prochlorophytes decreased slightly irrespective of dilution in the incubations over $24 \mathrm{~h}$, resulting in negative growth rates $(\mu)$ of -0.08 and $-0.03 \mathrm{~d}^{-1}$ at Stns 1 and 2, respectively. At Stns 3 and 4 , growth was $<0.01 \mathrm{~d}^{-1}$. In the aphotic zone of Stns 3 and 4, a low grazing loss of prochlorophytes, with $g$ of 0.08 and $0.13 \mathrm{~d}^{-1}$, respectively was calculated.
In the $24 \mathrm{~h}$ dilution incubations that were prepared after prescreening the natural water through pore sizes of 10,5 and $3 \mu \mathrm{m}$, apparent growth rates appeared to differ little from the corresponding dilutions prescreened through $200 \mu \mathrm{m}$ : Fig. 4 shows that growth rates measured after prefiltration through the smallest pore size of $3 \mu \mathrm{m}$ differed on average by $<5 \%$ from those in the corresponding $200 \mu \mathrm{m}$ treatments.

\section{In situ incubations}

The results of the in situ incubations in the upper and the central DCM are given in Table 2; the calculated gross growth rates $(\mu)$ and loss rates due to grazing $(g)$ measured over the whole $24 \mathrm{~h}$ and over the 12 daylight and 12 dark hours separately are shown in Fig. 5 (for reasons of comparison all data are expressed as $\mu \mathrm{h}^{-1}$ and $g \mathrm{~h}^{-1}$ ). Incubations of dilution series with 3 and $5 \mu \mathrm{m}$ prefiltered natural water resulted in similar growth and grazing rates. The $24 \mathrm{~h}$ gross growth rates for the prochlorophytes in the in situ incubations in the upper DCM varied between 0.15 and $0.36 \mathrm{~d}^{-1}$, and 
Table 2. Statistics for all Landry \& Hassett (1982) plots of deck and in situ incubations. Before fitting linear regressions, all measured $\mu_{\text {app }}\left(=k_{\mathrm{i}}\right)$ values in dilution bottles were standardized to $24 \mathrm{~h}$ estimates $\left(\mu_{\text {app }} \mathrm{d}^{-1}\right)$, resulting in intercepts representing $\mu \mathrm{d}^{-1}$ and slopes representing $g \mathrm{~d}^{-1}$. The last 2 columns show all estimated growth and grazing rates per hour. Corr. coeff.= correlation coefficients: for deck incubations, $\mathrm{n}=18$ throughout, trend $95 \%$ significant when $\mathrm{R}^{2}>0.219$; for in situ incubations, trend $95 \%$ significant when $\mathrm{R}^{2}>0.66$ for $\mathrm{n}=6$, and $>0.33$ for $\mathrm{n}=12$

\begin{tabular}{|c|c|c|c|c|c|c|c|c|c|}
\hline Stn & Time & $\begin{array}{l}\text { Size } \\
(\mu \mathrm{m})\end{array}$ & $\begin{array}{c}\text { Inital } \\
\text { abundance } \\
\left(\text { no. } \times 10^{4} \mathrm{ml}^{-1}\right)\end{array}$ & $\begin{array}{l}\text { Intercept } \\
=\mu\left(\mathrm{d}^{-1}\right)\end{array}$ & $\begin{aligned} & \text { Slope } \\
= & g\left(\mathrm{~d}^{-1}\right)\end{aligned}$ & (n) & $\begin{array}{l}\text { Corr. coeff. } \\
\mathrm{R}^{2}\end{array}$ & $\begin{array}{l}\text { Growth } \\
\text { rate } \\
\mu\left(\mathrm{h}^{-1}\right)\end{array}$ & $\begin{array}{l}\text { Grazing } \\
\text { rate } \\
g\left(\mathrm{~h}^{-1}\right)\end{array}$ \\
\hline \multicolumn{10}{|c|}{ Deck incubations: } \\
\hline \multicolumn{10}{|c|}{ Upper DCM } \\
\hline 1 & $24 \mathrm{~h}$ & $<200$ & 0.3 & 0.248 & -0.315 & (18) & 0.35 & 0.010 & 0.013 \\
\hline 2 & $24 \mathrm{~h}$ & $<200$ & 16.3 & 0.176 & -0.147 & (18) & 0.15 & 0.007 & 0.006 \\
\hline 3 & $24 \mathrm{~h}$ & $<200$ & 13.6 & 0.033 & -0.322 & (18) & 0.58 & 0.001 & 0.013 \\
\hline 4 & $24 \mathrm{~h}$ & $<200$ & 7.1 & 0.193 & -0.410 & (18) & 0.39 & 0.008 & 0.017 \\
\hline 5 & $24 \mathrm{~h}$ & $<200$ & 11.4 & 0.226 & -0.206 & (18) & 0.37 & 0.009 & 0.009 \\
\hline \multicolumn{10}{|l|}{ Central DCM } \\
\hline 1 & $24 \mathrm{~h}$ & $<200$ & 11.2 & 0.102 & 0.012 & $(18)$ & 0.01 & 0.004 & -0.001 \\
\hline 2 & $24 \mathrm{~h}$ & $<200$ & 9.8 & -0.110 & 0.015 & (18) & 0.02 & -0.005 & -0.001 \\
\hline 3 & $24 \mathrm{~h}$ & $<200$ & 5.8 & -0.010 & -0.041 & (18) & 0.07 & 0.000 & 0.002 \\
\hline 4 & $24 \mathrm{~h}$ & $<200$ & 1.3 & 0.157 & -0.118 & (18) & 0.32 & 0.007 & 0.005 \\
\hline 5 & $24 \mathrm{~h}$ & $<200$ & 10.9 & 0.055 & -0.132 & (18) & 0.57 & 0.002 & 0.005 \\
\hline \multicolumn{10}{|l|}{ Lower DCM } \\
\hline 1 & $24 \mathrm{~h}$ & $<200$ & 5.7 & -0.075 & 0.006 & $(18)$ & 0.00 & -0.003 & 0.000 \\
\hline 2 & $24 \mathrm{~h}$ & $<200$ & 3.0 & -0.033 & -0.040 & (18) & 0.14 & -0.001 & 0.002 \\
\hline 3 & $24 \mathrm{~h}$ & $<200$ & 2.4 & 0.002 & -0.079 & $(18)$ & 0.38 & 0.000 & 0.003 \\
\hline 4 & $24 \mathrm{~h}$ & $<200$ & 1.0 & 0.007 & -0.133 & (18) & 0.51 & 0.000 & 0.006 \\
\hline \multicolumn{10}{|c|}{ In situ incubations: } \\
\hline Upper DCM & $24 \mathrm{~h}$ & $<3$ & 9.3 & 0.327 & -0.059 & $(12)$ & 0.26 & 0.014 & 0.002 \\
\hline 19 Aug 1996 & $24 \mathrm{~h}$ & $<5$ & 9.8 & 0.298 & -0.086 & (6) & 0.57 & 0.012 & 0.004 \\
\hline \multirow[t]{4}{*}{4} & Day & $<3$ & 9.3 & 0.795 & -0.363 & (12) & 0.54 & 0.033 & 0.015 \\
\hline & Day & $<5$ & 9.8 & 0.742 & -0.297 & (6) & 0.47 & 0.031 & 0.012 \\
\hline & Night & $<3$ & 9.3 & -0.090 & 0.212 & (12) & 0.42 & -0.004 & -0.009 \\
\hline & Night & $<5$ & 9.8 & -0.097 & 0.103 & (6) & 0.26 & -0.004 & -0.004 \\
\hline 21 Aug 1996 & $24 \mathrm{~h}$ & $<3$ & 4.8 & 0.346 & -0.117 & (6) & 0.57 & 0.014 & 0.005 \\
\hline \multirow[t]{5}{*}{4} & $24 \mathrm{~h}$ & $<5$ & 5.0 & 0.356 & -0.205 & (12) & 0.66 & 0.015 & 0.009 \\
\hline & Day & $<3$ & 4.8 & 1.057 & -0.404 & (6) & 0.44 & 0.044 & 0.017 \\
\hline & Day & $<5$ & 5.0 & 1.143 & -0.505 & (12) & 0.76 & 0.048 & 0.021 \\
\hline & Night & $<3$ & 4.8 & -0.366 & 0.170 & (6) & 0.26 & -0.015 & -0.007 \\
\hline & Night & $<5$ & 5.0 & -0.431 & 0.095 & $(12)$ & 0.09 & -0.018 & -0.004 \\
\hline \multirow{6}{*}{$\begin{array}{l}27 \text { Aug } 1996 \\
5\end{array}$} & $24 \mathrm{~h}$ & $<3$ & 11.8 & 0.155 & -0.128 & (6) & 0.93 & 0.006 & 0.005 \\
\hline & $24 \mathrm{~h}$ & $<5$ & 11.8 & 0.146 & -0.135 & (12) & 0.45 & 0.006 & 0.006 \\
\hline & Day & $<3$ & 11.8 & 0.427 & -0.380 & (6) & 0.93 & 0.018 & 0.016 \\
\hline & Day & $<5$ & 11.8 & 0.364 & -0.282 & (12) & 0.56 & 0.015 & 0.012 \\
\hline & Night & $<3$ & 11.8 & -0.088 & 0.091 & (6) & 0.36 & -0.004 & -0.004 \\
\hline & Night & $<5$ & 11.8 & -0.065 & -0.025 & (12) & 0.01 & -0.003 & 0.001 \\
\hline Central DCM & $24 \mathrm{~h}$ & $<3$ & 5.5 & -0.018 & -0.007 & (6) & 0.02 & -0.001 & 0.000 \\
\hline 08 Aug 1996 & $24 \mathrm{~h}$ & $<5$ & 5.7 & -0.031 & -0.043 & (6) & 0.26 & -0.001 & 0.002 \\
\hline \multirow[t]{4}{*}{2} & Day & $<3$ & 5.5 & -0.057 & 0.047 & (6) & 0.23 & -0.002 & -0.002 \\
\hline & Day & $<5$ & 5.7 & 0.071 & -0.169 & (6) & 0.68 & 0.003 & 0.007 \\
\hline & Night & $<3$ & 5.5 & 0.034 & -0.079 & (6) & 0.54 & 0.001 & 0.003 \\
\hline & Night & $<5$ & 5.7 & -0.165 & 0.126 & (6) & 0.27 & -0.007 & -0.005 \\
\hline 12 Aug 1996 & $24 \mathrm{~h}$ & $<3$ & 44.4 & 0.014 & -0.116 & (6) & 0.94 & 0.001 & 0.005 \\
\hline \multirow[t]{5}{*}{3} & $24 \mathrm{~h}$ & $<5$ & 45.2 & 0.019 & -0.129 & (6) & 0.40 & 0.001 & 0.005 \\
\hline & Day & $<3$ & 44.4 & -0.270 & -0.134 & (6) & 0.95 & -0.011 & 0.006 \\
\hline & Day & $<5$ & 45.2 & -0.339 & -0.059 & (6) & 0.49 & -0.014 & 0.002 \\
\hline & Night & $<3$ & 44.4 & 0.250 & -0.011 & (6) & 0.85 & 0.010 & 0.000 \\
\hline & Night & $<5$ & 45.2 & 0.334 & -0.244 & (6) & 0.34 & 0.014 & 0.010 \\
\hline 25 Aug 1996 & $24 \mathrm{~h}$ & $<3$ & 5.0 & 0.006 & 0.062 & (6) & 0.31 & 0.000 & -0.003 \\
\hline \multirow[t]{5}{*}{5} & $24 \mathrm{~h}$ & $<5$ & 4.8 & 0.038 & 0.045 & (10) & 0.10 & 0.002 & -0.002 \\
\hline & Day & $<3$ & 5.0 & 0.001 & -0.083 & (6) & 0.04 & 0.000 & 0.003 \\
\hline & Day & $<5$ & 4.8 & -0.124 & 0.118 & (6) & 0.07 & -0.005 & -0.005 \\
\hline & Night & $<3$ & 5.0 & 0.206 & -0.019 & (10) & 0.00 & 0.009 & 0.001 \\
\hline & Night & $<5$ & 4.8 & 0.201 & -0.028 & (10) & 0.00 & 0.008 & 0.001 \\
\hline
\end{tabular}



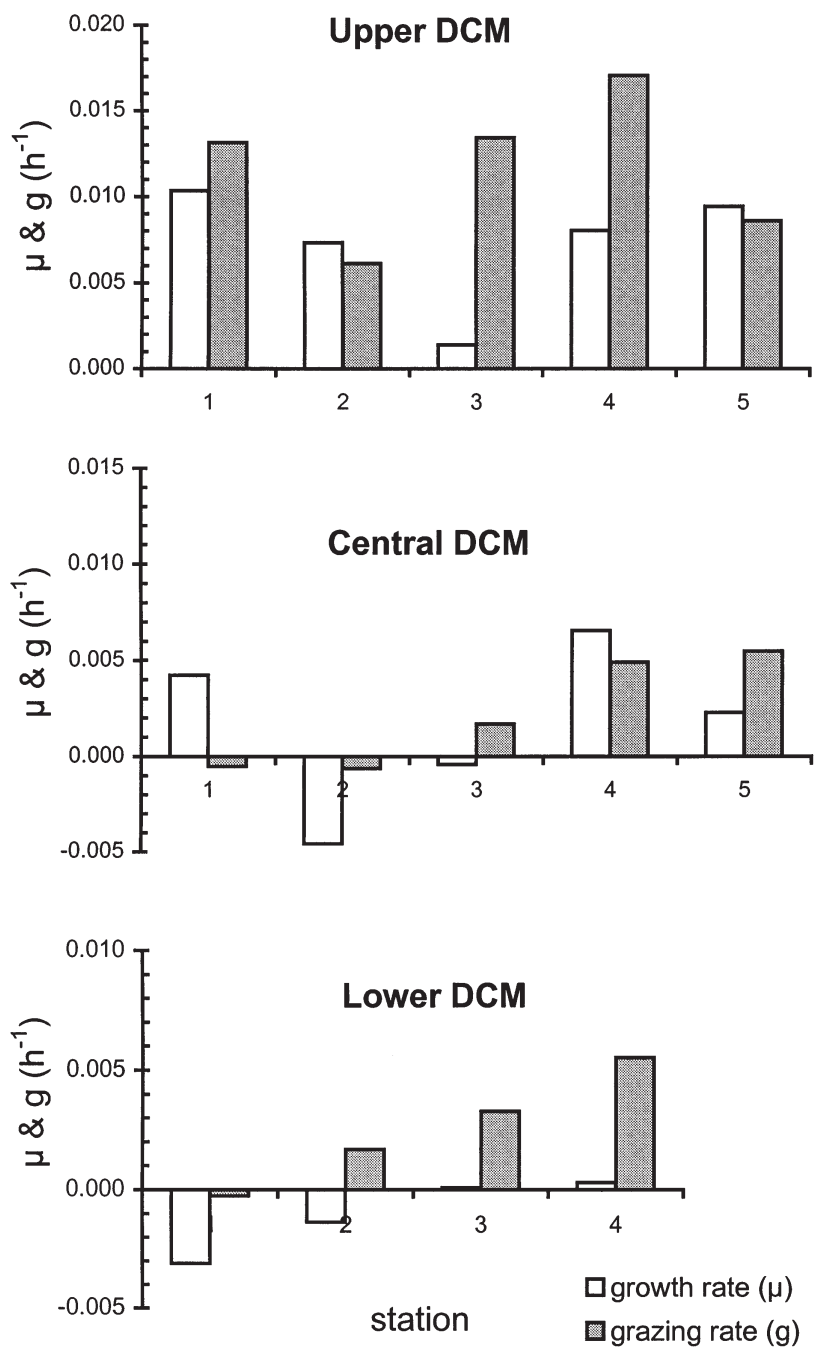

Fig. 3. Prochlorophytes. 24 h growth rates (open bars) and loss rates due to grazing (shaded bars) estimated by $200 \mu \mathrm{m}$ prescreened, shipboard, serial dilution incubations for 3 different layers in deep chlorophyll maximum layer (DCM) and 5 stations (see Table 2)

reached higher values than those measured in the $200 \mu \mathrm{m}$-filtered shipboard incubations (Table 2). Differentiating growth and grazing between day and night (Fig. 5) reveals a diel pattern in prochlorophyte growth and grazing in the upper DCM. Irrespective of prefiltration and station, cell numbers increased during the light period (between 06:00 and 18:00 h local time), but not in the dark (18:00 to 06:00 h), indicating that prochlorophyte cell division in the upper DCM occurred during the day. The daylight growth rates in the in situ incubations ranged from 0.015 to $0.047 \mathrm{~h}^{-1}$. During the $12 \mathrm{~h}$ dark incubation, however, no net growth was recorded (Fig. 5). Consequently, calculating $24 \mathrm{~h}$ growth rates based only on the $12 \mathrm{~h}$ light resulted in gross growth rates $\left(\mu \mathrm{d}^{-1}\right)$ twice as high as those calculated over a $24 \mathrm{~h}$ period. Grazing on prochlorophytes in the upper DCM was restricted to the daylight hours (Fig. 5, Table 2), and grazing rates $(g)$ based on the light observations only ranged between 0.012 and $0.021 \mathrm{~h}^{-1}$. Based on these daylight observations, daily grazing rates would be 0.28 to $0.50 \mathrm{~d}^{-1}$; taking the $12 \mathrm{~h}$ dark period without grazing into account, the $24 \mathrm{~h}$ grazing rate estimates for prochlorophytes would range from 0.14 to $0.25 \mathrm{~d}^{-1}$.

Fig. 5 also gives the results of the in situ incubations in the central DCM. Statistics and calculated growth and grazing rates are given in Table 2. Again, the 3 and $5 \mu \mathrm{m}$ prescreening led to only small differences. Gross growth rate $(\mu)$ calculated over $24 \mathrm{~h}$ ranged from -0.001 to $0.002 \mathrm{~h}^{-1}$ and, $24 \mathrm{~h}$ grazing rate $(g)$ from -0.003 to $0.005 \mathrm{~h}^{-1}$. Contrary to the pattern observed in the upper DCM (growth and grazing restricted to the daylight period 06:00 to 18:00 h), in the central DCM growth of prochlorophytes was not detectable during daytime, whereas gross growth rates $(\mu)$ during the night ranged from -0.007 to $0.014 \mathrm{~h}^{-1}$. Despite this considerable nocturnal growth at 2 out of 3 stations (Fig. 5), no grazing losses were detectable during the night in the central DCM corresponding to the situation in the upper DCM (Fig. 5), except for 1 out of 6 in situ dilution incubations which yielded a nocturnal grazing rate of $0.01 \mathrm{~h}^{-1}$. Grazing on prochlorophytes in the (sub)tropical North Atlantic seems therefore to take place mainly during the day, irrespective of depth in the photic zone or timing and extent of prochlorophyte cell division.

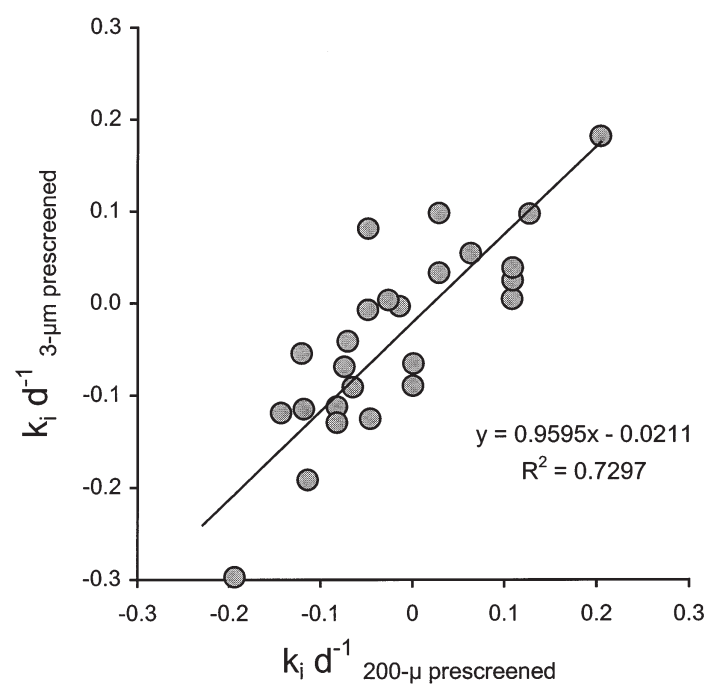

Fig. 4. Prochlorophytes. Comparison between $24 \mathrm{~h}$ growth rates $\left(k_{\mathrm{i}} \mathrm{d}^{-1}\right)$ measured after prefiltration through $200 \mu \mathrm{m}$ Nitex mesh and through $3 \mu \mathrm{m}$ polycarbonate filters in all available pairs of dilution bottles (40 and $100 \%$ ) of deck incubations, with linear regression 

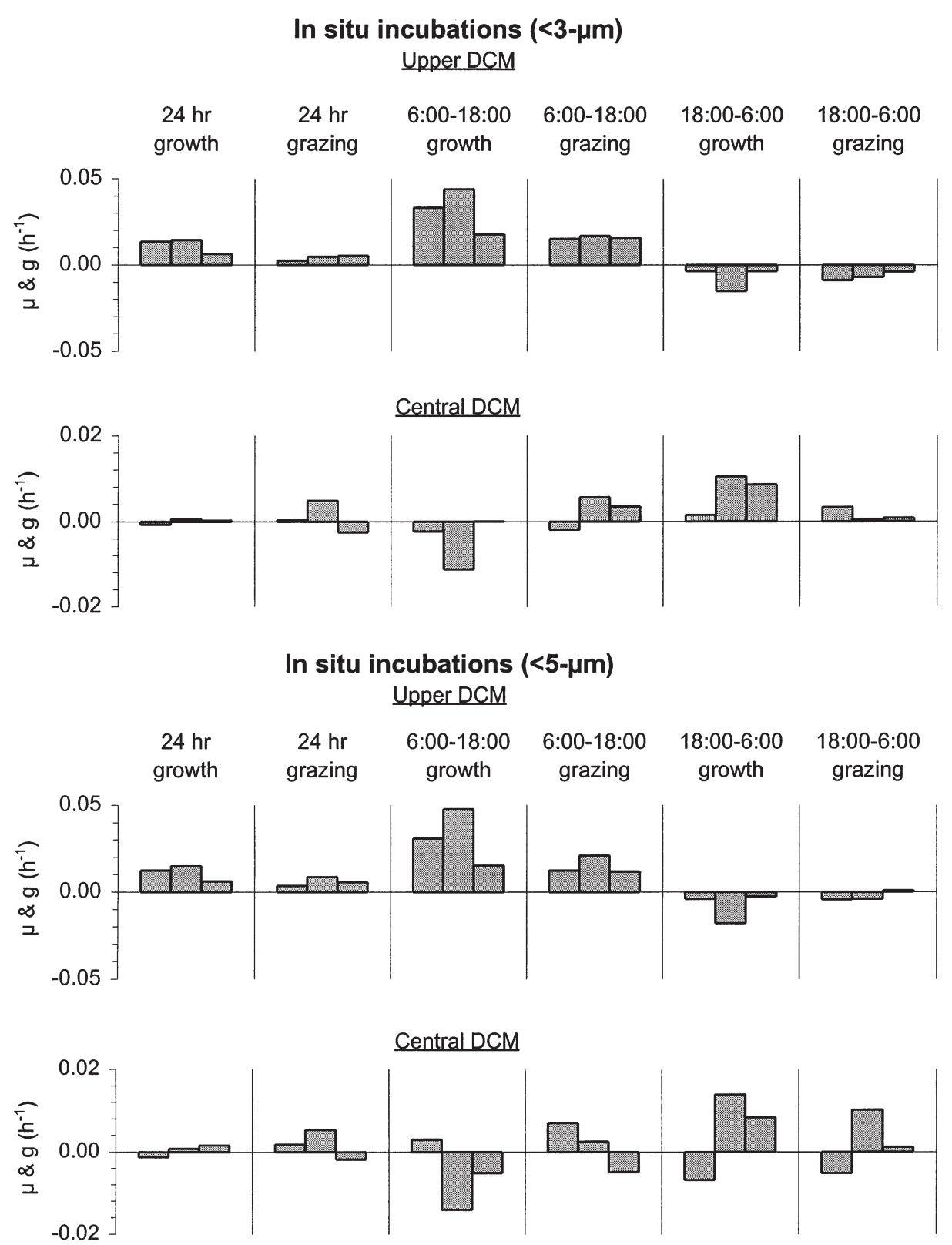

Fig. 5. Prochlorophytes. Growth rates, $\mu\left(\mathrm{h}^{-1}\right)$ and grazing rates, $g\left(\mathrm{~h}^{-1}\right)$ measured over $24 \mathrm{~h}$ and separately over $12 \mathrm{~h}$ daylight and $12 \mathrm{~h}$ night periods in the in situ incubation series in 2 of the 3 DCM layers (lower DCM not incubated). For statistics see Table 2

\section{DISCUSSION}

The prochlorophyte growth and grazing rates reported in this paper refer to the lower euphotic zone, where the highest $24 \mathrm{~h}$ gross growth rates were recorded in the upper layer of the 3 investigated water layers, i.e. above the actual fluorescence maximum layer. These $24 \mathrm{~h}$ growth rates $(\mu)$ were $0.25 \mathrm{~d}^{-1}$ $\left(=0.0103 \mathrm{~h}^{-1}\right)$ in deck incubations and $0.36 \mathrm{~d}^{-1}$ $\left(=0.015 \mathrm{~h}^{-1}\right)$ in the in situ incubation. They agree well with estimates based on ${ }^{14} \mathrm{C}$ incorporation in pro- chlorophytes from the Sargasso Sea (Goericke \& Welschmeyer 1993), where $\mu$ ranges from $0.3 \mathrm{~d}^{-1}$ in the surface to $0.1 \mathrm{~d}^{-1}$ in the bottom layers of the euphotic zone. Prochlorophyte growth rates in dilution experiments in the equatorial Pacific under normal upwelling conditions with high diatom growth rates of $1.7 \mathrm{~d}^{-1}$ were $0.5 \mathrm{~d}^{-1}$ (Latasa et al. 1997). Dilution experiments by Landry et al. (1995) yielded average overall growth rates based on chlorophyll $a$ of $0.8 \mathrm{~d}^{-1}$ for the near-surface, $0.34 \mathrm{~d}^{-1}$ for the mid- and $0.22 \mathrm{~d}^{-1}$ for the lowereuphotic zones in the equatorial Pacific. In the surface 
layer of the equatorial Pacific (a high- nutrient-lowchlorophyll area), almost 1 doubling $\mathrm{d}^{-1}$ in prochlorophytes was reported by Binder at al. (1996) on the basis of flow cytometer studies of the genom doubling cycle. However, in the lower euphotic zone, prochlorophytes do not attain 1 cell division $\mathrm{d}^{-1}$ (Vaulot \& Partensky 1992). These authors observed that most prochlorophyte cells are in the $\mathrm{G}_{(1)}$ phase (not actively cycling) when nitrate levels are below $0.4 \mu \mathrm{M}$ and light below $0.1 \%$ of the surface level.

According to Vaulot et al. (1995), DNA replication in prochlorophytes occurs in the afternoon and cell division at night (see also Partensky et al. 1999). In our in situ incubations, prochlorophyte numbers increased during the day in the upper DCM layer and during the night in the central DCM, indicating a major difference between the overlying DCM layer and the central DCM. In the model study by Bisset et al. (1999), prochlorophytes are categorized on the basis of literature data into a small, extremely light-inhibited, and a slightly larger, moderately light-inhibited Prochlorococcus species, which become dominant in different depth strata. It might be possible that the data of Vaulot et al. refer to 1 of these types, whereas we accidentally distinguished 2 Prochlorococcus species by their different cell-cycles.

Our average growth rates of $0.27 \mathrm{~d}^{-1}$ for the upper DCM and $0.005 \mathrm{~d}^{-1}$ for the central DCM (24 h in situ incubations) imply that the prochlorophytes of the lower euphotic zone need more than 3 light cycles to complete DNA replication. Part of the prochlorophyte community could be completely inactive at these depths (Vaulot \& Partensky 1992), the synchronized numerical increase being effected by a small share of the community or a better adapted strain of prochlorophytes which double more frequently. Obviously, the differences in frequency and timing of the division between the upper DCM layer and the central DCM reflect different optimum cell-cycle strategies in the actively growing part of the prochlorophyte community in these 2 habitats. Assuming that photosynthesis and nutrient incorporation temporarily cease during cell division, the best survival strategy for the light-limited cells of the central DCM would be to divide in the dark. On the other hand, at shallower depths where nutrients instead of light are limiting prochlorophyte growth, and nutrient depletion will be more severe during the light period, division in daylight could be the optimal strategy in respect to nutrient uptake.

Passing grazers of prochlorophytes in the lower euphotic zone through $3 \mu \mathrm{m}$ polycarbonate filters has no noticeable effect on community grazing pressure (Fig. 4). Caron et al. (1999) found unaltered grazing rates by consumers of picoplankton in the Sargasso Sea even after filtering through $2 \mu \mathrm{m}$ pore-size filters.
This suggests that small nanoflagellates are the predominant grazers of prochlorophytes. In those cases where these HNANs measured from $1 \mu \mathrm{m}$ to slightly over $3 \mu \mathrm{m}$, our prescreened incubations may have contained more than 2 trophic levels. This could (in addition to variance in the data) explain the negative grazing rates observed in some of the dilution series as arising from deceased predation on the smallest HNANs in the most dilute bottles resulting in heavier grazing on the prochlorophytes. The fact that negative grazing occurred more in the $5 \mu \mathrm{m}$ than in the $3 \mu \mathrm{m}$ prescreened incubations seems to support this view (Fig. 5).

In a previous study, we found for the same site that heterotrophic bacteria divide mainly between 24:00 and 06:00 h, based on cell-size distribution and frequency of dividing cells (Kuipers et al. 2000). Fig. 6 shows the bacterial counts of Stns 2 to 5 from Kuipers et al. (2000) for the different sampled layers as a function of time of day. A plausible explanation for the equal trends in bacterial abundance in the 3 investigated layers in the euphotic zone at all 4 stations in Fig. 6 is that after synchronous nightly bacterial division fairly heavy grazing by HNANs during the morning hours reduced the bacterial community to its original abundance of $8 \times 10^{5} \mathrm{ml}^{-1}$. After 12:00 h grazing ceased, possibly because the threshold level for profitable grazing had been reached (Fenchel 1984). The results of the different prescreening treatments suggest that the HNANs, with their diel grazing cycle, may consume encountered prochlorophytes together with the heterotrophic bacteria. Abundance of prochlorophytes is lower than that of heterotrophic bacteria, and they would, at the threshold level of $8 \times$ $10^{5} \mathrm{ml}^{-1}$ constitute no profitable prey in themselves. Fig. 7 shows a positive correlation between grazing rates during the 12 daylight hours on prochlorophytes (present dilution experiments) and on heterotrophic bacteria from the same depth layers (population rates decreased during the period 06:00 to 18:00 h based on bacterial abundance data from Kuipers et al. (2000) (Fig. 6). Although the bacteria were sampled on different days than the prochlorophytes and the loss rates due to grazing were estimated in different ways, grazing pressures on both groups co-vary. Insofar as they did not arise from differences in methods, the lower grazing rates for prochlorophytes than for bacteria could indicate a higher preference of HNANs for hetero-trophic bacteria, although it seems unlikely that prochlorophytes of the same size as bacteria would be rejected by grazing HNANs. There are, however, also purely mechanical explanations for the observed difference in grazing rate. The dependence of encounter rate on motility of the prey as described by Fenchel (1984) could theoretically lead to a 2- to 3-fold higher 

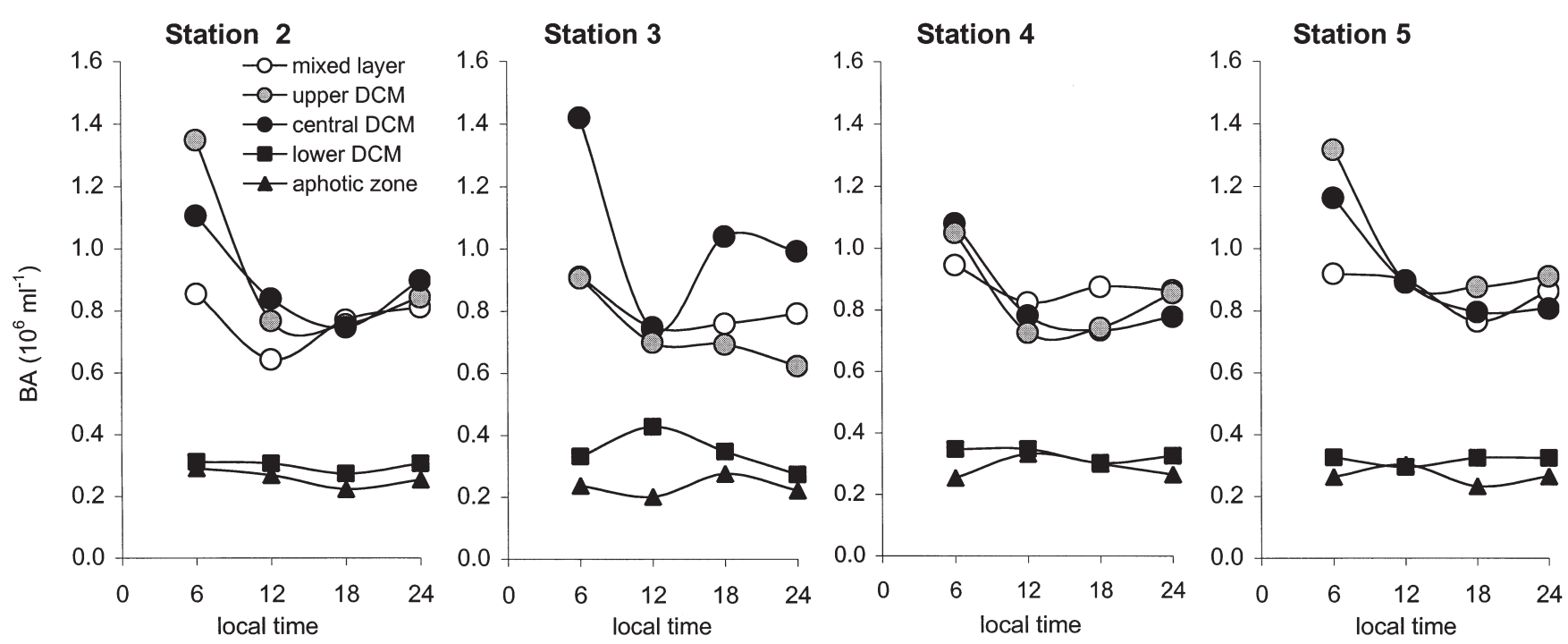

Fig. 6. Diel trends in abundance of heterotrophic bacteria (BA) at Stns 2 to 5, enumerated by epifluorescence microscopy after DAPI-staining (original data and details of methods in Kuipers et al. 2000, no data available for Stn 1)

encounter rate for bacteria, since these are motile and prochlorophytes are not. Another explanation, offered by Monger et al. (1999), is that feeding selection of HNANs is based on a positive relationship between clearance rate and the surface hydrophobicity of the prey. According to Monger et al., the hydrophobicity of Prochlorococcus spp. around the depth of the thermocline in the oligotrophic subtropical Pacific station Aloha is lower than that of heterotrophic bacteria. If this is also true for the subtropical Atlantic, it could explain the higher clearance rate of bacteria than prochlorophytes in the presently studied DCM layers quite well.

Additional evidence that the period of most intensive grazing on prochlorophytes is regulated by the predator-prey relationship between HNANs and heterotrophic bacteria is the observation (Table 2) that grazing on prochlorophytes does not show any relationship to the abundance of the prochlorophytes, nor to their growth rate and time of division. The results of Dolan \& Simek (1999) on Synechococcus spp. in the NW Mediterranean showed a similar pattern, with HNAN grazing restricted to the morning hours and peak vacuole contents at 10:00 to $12: 00 \mathrm{~h}$, despite the fact that frequency of dividing cells in Synechococcus spp. was maximum in the evening and numbers increased at night. These authors explain the absence of grazing at the time the prey is present in maximum densities as 'hiding' of Synechococcus spp. by division into a size range at which the cells are too small for efficient grazing to occur. Our explanation of the dependence of HNAN grazing activity on the abundance of heterotrophic bacteria, with grazing on other prey items (prochlorophytes) as a by-product, would explain the results of Dolan \& Simek equally well. Fig. 8 presents the different cell cycles of all these picoplankton groups, showing the similarity of the period of most intensive grazing for all groups.

One conclusion of our hypothesis that prochlorophytes are a 'by-catch' of HNANs is the lack of density dependent-grazing by HNANs on prochlorophytes. Obviously, their abundance is limited by more mechanisms than bacteria-regulated grazing. Cell lysis during unfavorable intervals and virus control are possible loss factors which, together with HNAN grazing, balance prochlorophyte growth. In a theoretical study, Bratbak \& Thingstad (1985) suggested another plausible explanation, that lower affinity in prochlorophytes

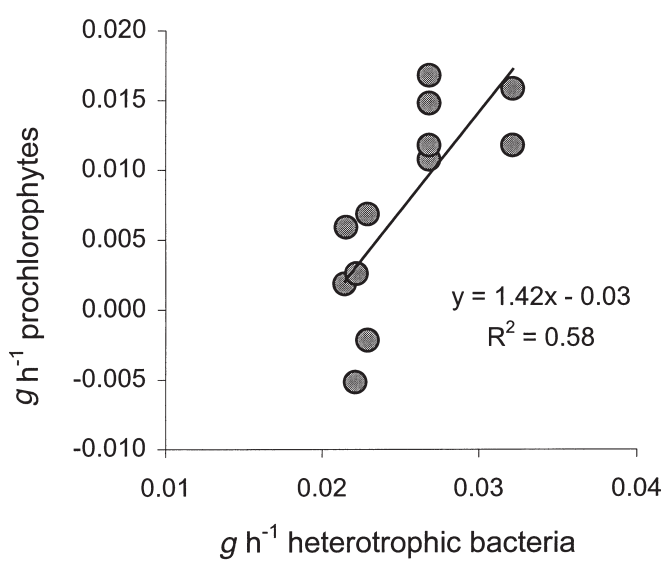

Fig. 7. Comparison between grazing rates measured for prochlorophytes over $12 \mathrm{~h}$ daylight periods (this study) and grazing rates calculated for heterotrophic bacteria over same part of day in same DCM layers, with linear regression (data from Kuipers et al. 2000, see also Fig. 6) 


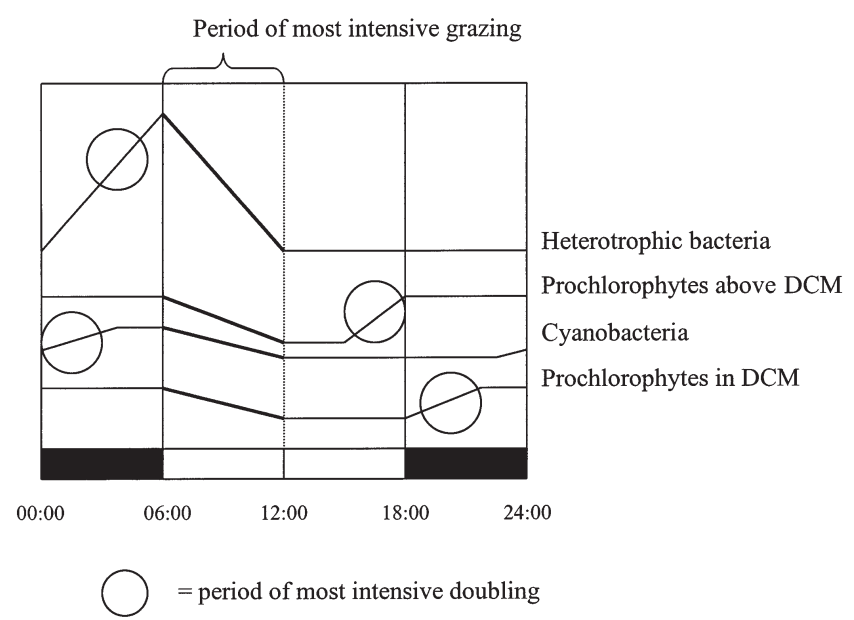

Fig. 8. Diel fluctuation in abundance of heterotrophic bacteria (no. $\mathrm{ml}^{-1} 0.7$ to $1.4 \times 10^{6}$ : Fig. 6), cyanobacteria (no. $\mathrm{ml}^{-1} 2$ to $4 \times 10^{4}$ : Dolan \& Simek 1999) and 2 strains of prochlorophytes (no. $\mathrm{ml}^{-1} 1$ to $45 \times 10^{4}$ : Table 2 ) which are all grazed synchronously with heterotrophic bacteria although dividing at different times of day

than in heterotrophic bacteria for the growth-limiting nutrients for which they compete would generally lead to the observed moderate presence of prochlorophytes in the total picoplankton.

Another argument in favor of density-independent HNAN-grazing on prochlorophytes is the latter's occurrence in highly varying numbers under very similar conditions (Table 2). As argued by Vaulot \& Partensky (1992), prochlorophytes may grow slowly in nitrogen-depleted waters, but still have the potential to respond quickly to nitrogen pulses. As observed in other areas, exceptional eddies leading to upwelling of nutrients into the euphotic zone may cause rapid new production in prochlorophytes in the (sub)tropical North Atlantic DCM. This would probably happen rather unpredictably in time and space, without much numerical or functional response in the bacteria-feeding HNANs. Olaizola et al. (1993) observed only weak grazing in the subtropical Pacific after a more than 2-fold increase of the DCM chlorophyll concentration, and concluded that coupling between phytoplankton and grazers was weak.

Summarizing the results of the present grazing study:

(1) Growth rates of the prochlorophytes in the lower euphotic zone are $\sim 0.3 \mathrm{~d}^{-1}$ and decrease with increasing depth to negative values below the depth of peak fluorescence. In contrast to most literature data, the timing of prochlorophyte cell division changed with depth from doubling in daylight slightly above the DCM to doubling in the night in the actual DCM. (2) Prochlorophytes in the (sub)tropical North Atlantic are grazed at rates of 0.0 to $0.4 \mathrm{~g} \mathrm{~d}^{-1}$ by heterotrophic nanoflagellates. We suggest that the periodicity and intensity of this grazing are regulated by the diel cycle in availability, above a threshold level of $0.8 \times 10^{6}$ cells $\mathrm{ml}^{-1}$, of the much more abundant primary food source of HNANs-heterotrophic bacteria.

Acknowledgements. We thank the officers and the crew of HRMS 'Tydeman' for their excellent support during the cruise, Gerhard Herndl and Roel Riegman for their critical comments on the manuscript, and Gijs Kraay and Marcel Veldhuis for the guidance during the flow cytometry. This cruise program was funded by the Netherlands Geoscience Foundation NOW.

\section{LITERATURE CITED}

Binder BJ, Chisholm SW, Olson RJ, Frankel SL, Worden AZ (1996) Dynamics of picophytoplankton, ultraphytoplankton and bacteria in the central equatorial Pacific. DeepSea Res (II)43:907-931

Bisset WP, Walsh JJ, Dieterle DA, Carder KL (1999) Carbon cycling in the upper waters of the Sargasso Sea. I. Numerical simulation of differential carbon and nitrogen fluxes. Deep-Sea Res (I)46:271-273

Bratbak G, Thingstad TF (1985) Phytoplankton-bacteria interactions: an apparent paradox? Analysis of a model system with both competition and commensalism. Mar Ecol Prog Ser 25:23-30

Campbell L, Vaulot D (1993) Photosynthetic picoplankton community structure in the Subtropical North Pacific Ocean near Hawaii (station ALOHA). Deep-Sea Res (I)40: 2043-2060

Caron DA, Peele ER, Ee LL, Denett MR (1999) Picoplankton and nanoplankton and their trophic coupling in surface waters of the Sargasso Sea south of Bermuda. Limnol Oceanogr 44:259-272

Claustre H, Marty JC (1995) Specific phytoplankton biomasses and their relation to primary production in the Tropical North Atlantic. Deep-Sea Res (I)42:1475-1493

Dolan JR, Simek K (1999) Diel periodicity in Synechococcus populations and grazing by heterotrophic nanoflagellates: analysis of food vacuole contents. Limnol Oceanogr 44: 1565-1570

Fenchel T (1984) Suspended marine bacteria as food source. In: Fasham MJ (ed) Energy and materials in marine ecosystems. Plenum Press, New York, p 301-315

Gieskes WW, Kraay GW (1986) Floristic and physiological differences between the shallow and the deep nanophytoplankton community in the euphotic zone of the open tropical Atlantic revealed by HPLC analysis of pigments. Mar Biol 91:567-576

Goericke R, Repeta DJ (1992) The pigments of Prochlorococcus marinus: the presence of divinyl chlorophyll a and b in a marine procaryote. Limnol Oceanogr 37:425-433

Goericke R, Repeta DJ (1993) Chlorophylls a and b and divinyl chlorophylls a and b in the open Subtropical North Atlantic Ocean. Mar Ecol Prog Ser 101:307-313

Goericke R, Welschmeyer NA (1993) The marine prochlorophyte Prochlorococcus contributes significantly to phytoplankton biomass and primary production in the Sargasso Sea. Deep-Sea Res (I) 40:2283-2294

Jochem FJ (1995) Phototrophic picoplankton community 
structure in three different pelagic regimes in the Arabian Sea. Mar Ecol Prog Ser 117:307-314

Kirk JTO (1983) Light and photosynthesis in aquatic systems. Cambridge University Press, Cambridge

Kuipers BR, Witte HJ (1999) Grazing impact of microzooplankton on different size-classes of algae in the North Sea in early spring and mid-summer. Mar Ecol Prog Ser 180:93-104

Kuipers BR, van Noort GJ, Vosjan JH, Herndl GJ (2000) Diel periodicity of bacterioplankton in the euphotic zone of the subtropical Atlantic Ocean. Mar Ecol Prog Ser 201:13-25

Landry MR, Hassett RP (1982) Estimating the grazing impact of marine micro-zooplankton. Mar Biol 67:283-288

Landry MR, Constantinou J, Kirshtein J (1995) Microzooplankton grazing in the Central Equatorial Pacific during February and August, 1992. Deep-Sea Res (II)42:657-671

Landry MR, Kirshtein J, Constantinou J (1996) Abundances and distribution of picoplankton populations in the central equatorial Pacific from $120 \mathrm{~N}$ to $120 \mathrm{~S}, 1400 \mathrm{~W}$. Deep-Sea Res (II)43:871-890

Latasa M, Landry MR, Schlueter L, Bidigare RR (1997) Pigment-specific growth and grazing rates of phytoplankton in the central equatorial Pacific. Limnol Oceanogr 42: 289-298

Li WKW, Dickie PM, Irwin BD, Wood AM (1992) Biomass of bacteria, cyanobacteria, prochlorophytes and photosynthetic eukaryotes in the Sargasso Sea. Deep-Sea Res 39:501-519

McManus GB, Dawson R (1994) Phytoplankton pigments in the deep chlorophyll maximum of the Caribbean Sea and the western Tropical Atlantic Ocean. Mar Ecol Prog Ser 113:199-206

Monger BC, Landry MR, Brown SL (1999) Feeding selection of heterotrophic marine nanoflagellates based on the surface hydrophobicity of their picoplankton prey. Limnol Oceanogr 44:1917-1927

Editorial responsibility: Otto Kinne (Editor),

Oldendorf/Luhe, Germany
Neveux J (ed) (1992) Les maximums profonds de chl a en mer des Sargasses. Donnees physiques et biologiques Campagne Chlomax, 14 septembre - 13 octobre 1987. Campagnes Oceanogr Fr (IFREMER) 17:1-137

Olaizola M, Ziemann DA, Bienfang PK, Walsh WA, Conquest LD (1993) Eddy-induced oscillations of the pycnocline affect the floristic composition of phytoplankton in the subtropical Pacific. Mar Biol 116:533-542

Olson RJ, Chisholm SW, Zettler ER, Altabet MA, Dusenberry JA (1990) Spatial and temporal distributions of prochlorophyte picoplankton in the North Atlantic Ocean. DeepSea Res (I)37:1033-1051

Partensky F, Blanchot J, Lantoine F, Neveux J, Marie D (1996) Vertical structure of picophytoplankton at different trophic sites of the tropical northeastern Atlantic Ocean. DeepSea Res (I)43:1191-1213

Partensky F, Hess WR, Vaulot D (1999) Prochlorococcus, a marine photosynthetic prokryote of global significance. Microbiol Molec Biol Rev Mar 1999:106-127

Shimada A, Hasegawa T, Umeda I, Kadoya N, Maruyama T (1993) Spatial mesoscale patterns of West Pacific picoplankton as analyzed by flow cytometry: their contribution to subsurface chlorophyll maxima. Mar Biol 115: 209-215

Vaulot D, Partensky F (1992) Cell cycle distribition of prochlorophytes in the North Western Mediterranean Sea. Deep-Sea Res (I)39:727-742

Vaulot D, Marie D, Olson RJ, Chisholm SW (1995) Growth of Prochlorococcus, a photosynthetic prokaryote, in the Equatoral Pacific Ocean. Science 268:1480-1482

Veldhuis MJW, Kraay GW (1990) Vertical distrubution and pigment composition of a picoplanktonic prochlorophyte in the subtropical North Atlantic: a combined study of HPLC-analysis of pigments and flow cytometry. Mar Ecol Prog Ser 68:121-127

Submitted: December 30, 1999; Accepted: May 18, 2000

Proofs received from author(s): September 4, 2000 